\title{
Seasonal impact of biogenic VSL bromine on the evolution of mid-latitude lowermost stratospheric ozone during the $21^{\text {st }}$ century
}

Javier A. Barrera ${ }^{1}$, Rafael P. Fernandez ${ }^{1,2,3}$, Fernando Iglesias-Suarez ${ }^{2}$, Carlos A. Cuevas $^{2}$, Jean-Francois Lamarque ${ }^{4}$ and Alfonso Saiz-Lopez ${ }^{2}$

${ }^{1}$ Institute for Interdisciplinary Science, National Research Council (ICBCONICET), FCEN-UNCuyo, Mendoza, 5500, Argentina.

${ }^{2}$ Department of Atmospheric Chemistry and Climate, Institute of Physical Chemistry Rocasolano, CSIC, Madrid, 28006, Spain.

${ }^{3}$ Atmospheric and Environmental Studies Group (GEAA), UTN-FRM, Mendoza, 5500, Argentina.

${ }^{4}$ Atmospheric Chemistry, Observations \& Modelling Laboratory, National Center for Atmospheric Research, Boulder, CO 80301, USA 
Table S1. Heterogeneous reactions on ice-crystals and sulphate aerosols involving halogens in CAM-Chem.

\begin{tabular}{|c|c|c|}
\hline & Reactions & Comments \\
\hline \multicolumn{3}{|c|}{ Ice-crystal } \\
\hline Het1 & $\mathrm{N}_{2} \mathrm{O}_{2}+\mathrm{H}_{2} \mathrm{O} \rightarrow 2 \mathrm{HNO}_{3}$ & $*$ \\
\hline Het2 & $\mathrm{ClONO}_{2}+\mathrm{H}_{2} \mathrm{O} \rightarrow \mathrm{HOCl}+\mathrm{HNO}_{3}$ & * \\
\hline Het3 & $\mathrm{BrONO}_{2}+\mathrm{H}_{2} \mathrm{O} \rightarrow \mathrm{HOBr}+\mathrm{HNO}_{3}$ & $*$ \\
\hline Het4 & $\mathrm{ClONO}_{2}+\mathrm{HCl} \rightarrow \mathrm{Cl}_{2}+\mathrm{HNO}_{3}$ & $*$ \\
\hline Het5 & $\mathrm{HOCl}+\mathrm{HCl} \rightarrow \mathrm{Cl}_{2}+\mathrm{H}_{2} \mathrm{O}$ & $*$ \\
\hline Het6 & $\mathrm{HOBr}+\mathrm{HCl} \rightarrow \mathrm{BrCl}+\mathrm{H}_{2} \mathrm{O}$ & $*$ \\
\hline \multicolumn{3}{|c|}{ Sulfate aerosol reactions } \\
\hline Het7 & $\mathrm{N}_{2} \mathrm{O}_{2}+\mathrm{H}_{2} \mathrm{O} \rightarrow 2 \mathrm{HNO}_{3}$ & $*$ \\
\hline Het8 & $\mathrm{ClONO}_{2}+\mathrm{H}_{2} \mathrm{O} \rightarrow \mathrm{HOCl}+\mathrm{HNO}_{3}$ & $*$ \\
\hline Het9 & $\mathrm{BrONO}_{2}+\mathrm{H}_{2} \mathrm{O} \rightarrow \mathrm{HOBr}+\mathrm{HNO}_{3}$ & $*$ \\
\hline Het10 & $\mathrm{ClONO}_{2}+\mathrm{HCl} \rightarrow \mathrm{Cl}_{2}+\mathrm{HNO}_{3}$ & * \\
\hline Het11 & $\mathrm{HOCl}+\mathrm{HCl} \rightarrow \mathrm{Cl}_{2}+\mathrm{H}_{2} \mathrm{O}$ & $*$ \\
\hline Het12 & $\mathrm{HOBr}+\mathrm{HCl} \rightarrow \mathrm{BrCl}+\mathrm{H}_{2} \mathrm{O}$ & $*$ \\
\hline
\end{tabular}

* As in Table A4 from Auxiliary Material in Kinnison et al. (2007).

For a complete list of heterogeneous reactions implemented in CAM-Chem see Table 4 in the Supplementary Material of Ordoñez et al. (2012). 
Table S2. Odd oxygen (Ox) loss rates reactions grouped by family cycles

\begin{tabular}{|c|c|c|c|}
\hline Family & Reaction & $\Delta \mathrm{O}_{\mathrm{x}}$ & Odd oxygen loss ${ }^{\S}$ \\
\hline \multirow[t]{2}{*}{$\mathrm{O}_{\mathrm{x}}$} & $\mathrm{O}+\mathrm{O}_{3} \rightarrow 2 \times \mathrm{O}_{2}$ & -2 & $\mathrm{Ox}_{-\mathrm{Loss}}=2 \times R_{\mathrm{O}+\mathrm{O} 3}+R_{\mathrm{O} 1 \mathrm{D}+\mathrm{H} 2 \mathrm{O}}$ \\
\hline & $\mathrm{O}(1 \mathrm{D})+\mathrm{H}_{2} \mathrm{O} \rightarrow 2 \times \mathrm{OH}$ & -1 & \\
\hline \multirow[t]{2}{*}{$\mathrm{HO}_{\mathrm{x}}$} & $\mathrm{HO}_{2}+\mathrm{O} \rightarrow \mathrm{OH}+\mathrm{O}_{2}$ & $-2^{\dagger}$ & $\mathrm{HOX}_{-\mathrm{Loss}}=2 \times\left(R_{\mathrm{HO} 2+\mathrm{O}}+R_{\mathrm{HO} 2+\mathrm{O} 3}\right)$ \\
\hline & $\mathrm{HO}_{2}+\mathrm{O}_{3} \rightarrow \mathrm{OH}+2 \times \mathrm{O}_{2}$ & $-2^{\dagger}$ & \\
\hline \multirow[t]{2}{*}{$\mathrm{NO}_{\mathrm{x}}$} & $\mathrm{NO}_{2}+\mathrm{O} \rightarrow \mathrm{NO}+\mathrm{O}_{2}$ & -2 & $\mathrm{NOx}_{- \text {Loss }}=2 \times\left(R_{\mathrm{NO} 2+\mathrm{O}}+J_{\mathrm{NO} 3}\right)$ \\
\hline & $\mathrm{NO}_{3}+h v \rightarrow \mathrm{NO}+\mathrm{O}_{2}$ & -2 & \\
\hline \multirow[t]{10}{*}{ Halog } & $\mathrm{ClO}+\mathrm{O} \rightarrow \mathrm{Cl}+\mathrm{O}_{2}$ & -2 & $\mathrm{ClOx}_{-\mathrm{L} \text { oss }}=2 \times\left(R_{\mathrm{ClO}+\mathrm{O}}+J_{\mathrm{CL} 2 \mathrm{O} 2}+R_{\mathrm{ClO}+\mathrm{ClO}}{ }^{a}+R_{\mathrm{ClO}+\mathrm{ClO}}{ }^{b}+R_{\mathrm{ClO}+\mathrm{HO} 2}\right)$ \\
\hline & $\mathrm{Cl}_{2} \mathrm{O}_{2}+h v \rightarrow 2 \times \mathrm{Cl}+\mathrm{O}_{2}$ & -2 & \\
\hline & $\mathrm{ClO}+\mathrm{ClO} \rightarrow \mathrm{Cl}_{2}+\mathrm{O}_{2}$ & -2 & \\
\hline & $\mathrm{ClO}+\mathrm{ClO} \rightarrow \mathrm{Cl}+\mathrm{OClO}$ & -2 & \\
\hline & $\mathrm{ClO}+\mathrm{HO}_{2} \rightarrow \mathrm{HOCl}+\mathrm{O}_{2}$ & $-2^{£}$ & \\
\hline & $\mathrm{BrO}+\mathrm{O} \rightarrow \mathrm{Br}+\mathrm{O}_{2}$ & -2 & $\mathrm{BrOX}_{-\mathrm{Loss}}=2 \times\left(R_{\mathrm{BrO}+\mathrm{O}}+R_{\mathrm{BrO}+\mathrm{BrO}}+R_{\mathrm{BrO}+\mathrm{HO} 2}\right)$ \\
\hline & $\mathrm{BrO}+\mathrm{BrO} \rightarrow 2 \times \mathrm{Br}+\mathrm{O}_{2}$ & -2 & \\
\hline & $\mathrm{BrO}+\mathrm{HO}_{2} \rightarrow \mathrm{HOBr}+\mathrm{O}_{2}$ & $-2^{\mathfrak{E}}$ & \\
\hline & $\mathrm{BrO}+\mathrm{ClO} \rightarrow \mathrm{Br}+\mathrm{Cl}+\mathrm{O}_{2}$ & -2 & $\mathrm{ClOxBrOx}_{-\mathrm{Loss}}=2 \times\left(R_{\mathrm{BrO}+\mathrm{ClO}}^{b}+R_{\mathrm{BrO}+\mathrm{ClO}}^{c}\right)$ \\
\hline & $\mathrm{BrO}+\mathrm{ClO} \rightarrow \mathrm{BrCl}+\mathrm{O}_{2}$ & -2 & \\
\hline
\end{tabular}

$\mathrm{O}_{\mathrm{x}}=\mathrm{O}(3 \mathrm{P})+\mathrm{O}(1 \mathrm{D})+\mathrm{O}_{3}+\mathrm{NO}_{2}+2 \times \mathrm{NO}_{3}+\mathrm{HNO}_{3}+\mathrm{HO}_{2} \mathrm{NO}_{2}+2 \times \mathrm{N}_{2} \mathrm{O}_{5}+\mathrm{ClO}+2 \times \mathrm{Cl}_{2} \mathrm{O}_{2}+2 \times \mathrm{OClO}+2 \times \mathrm{CLONO}_{2}+\mathrm{BrO}+2 \times \mathrm{BrONO}_{2}$ 
${ }^{\S} R_{A+B}$ is the reaction rate for reaction $\mathrm{A}+\mathrm{B} \rightarrow$ products and $J_{C}$ is the photodissociation rate constant (i.e. photolysis $\times$ concentration) for C+hv $\rightarrow$ products. Units are molec. $\mathrm{cm}^{-3} \mathrm{~s}^{-1}$.

${ }^{\dagger} \mathrm{HO}_{\mathrm{x}}$ loss cycles represent a net change $2 \mathrm{O}_{3} \rightarrow 3 \mathrm{O}_{2}\left(\Delta \mathrm{O}_{\mathrm{x}}=-2\right)$ due to reactions $\mathrm{OH}+\mathrm{O} \rightarrow \mathrm{H}+\mathrm{O}_{2}$ and $\mathrm{OH}+\mathrm{O}_{3} \rightarrow \mathrm{HO}_{2}+\mathrm{O}_{2}$. As $\mathrm{O}_{\mathrm{x}}$ reactions with $\mathrm{OH}$ are faster than with $\mathrm{HO}_{2}$, only the rate determining steps (RDS) have been considered multiplied by two.

${ }^{\mathrm{f}}$ Reactions $\mathrm{XO}+\mathrm{HO}_{2} \rightarrow \mathrm{HOX}+\mathrm{O}_{2}$, with $\mathrm{X}=\mathrm{Cl}$ or $\mathrm{Br}$, have been computed for each family with $\Delta \mathrm{O}_{\mathrm{x}}=-2$ because the photolysis of $\mathrm{HOX}$ produces an additional $\mathrm{O}_{\mathrm{x}}$ loss by the $\mathrm{OH}$ radical (i.e. $\mathrm{OH}+\mathrm{O}_{3} \rightarrow \mathrm{HO}_{2}+\mathrm{O}_{2}$ ). As these $\mathrm{XO}+\mathrm{HO} 2$ reaction are the rate limiting step, their loss rates have been multiplied by two. 

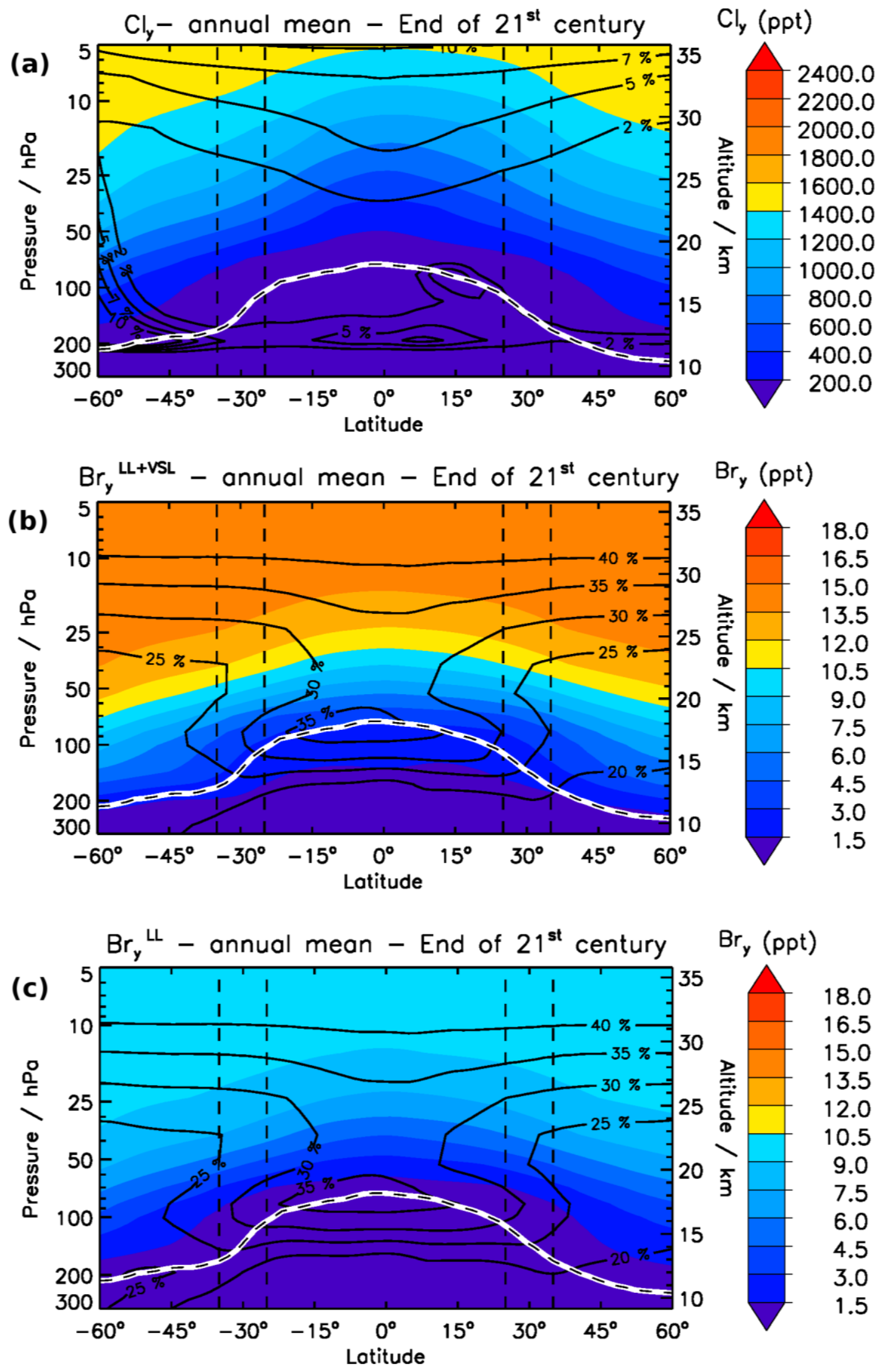

Figure S1: As Fig. 2 but for the end of the $21^{\text {st }}$ century period. 


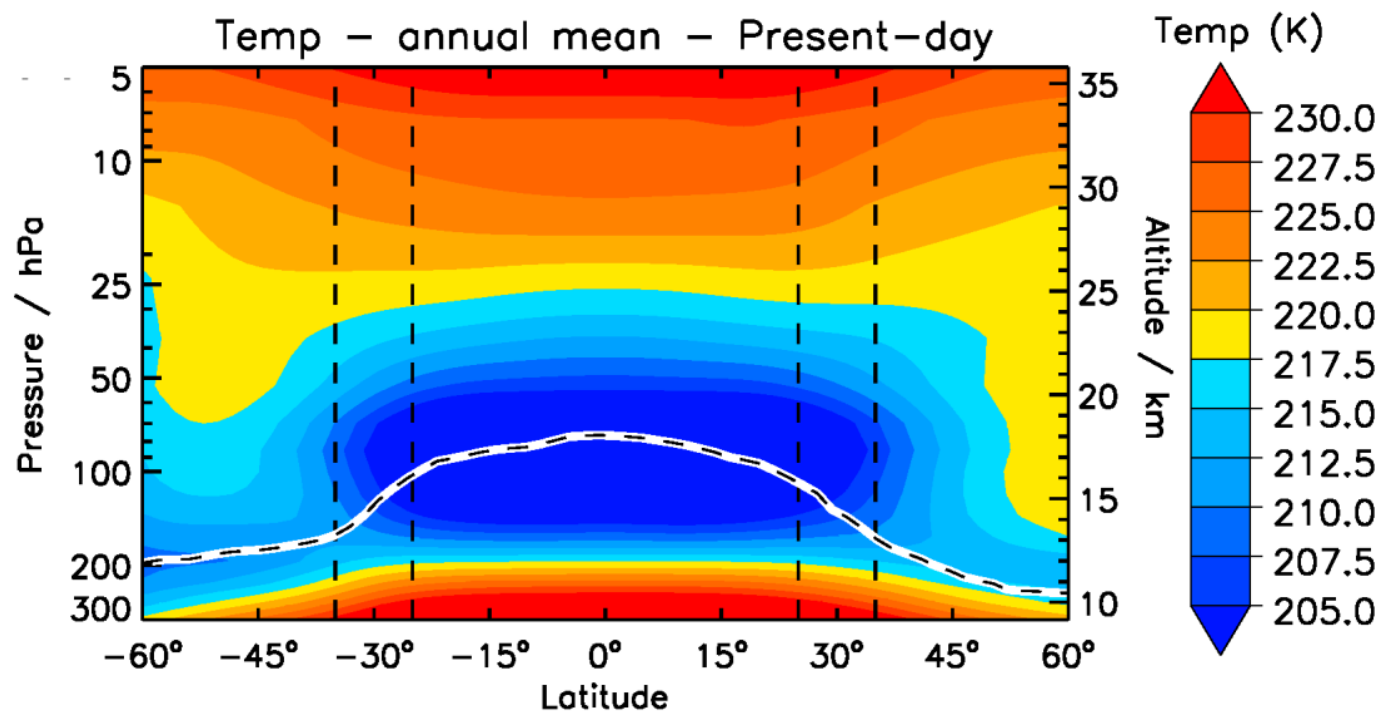

Figure S2: Annual zonal mean Temperature (K) for the present-day period. The lower solid white line indicates the location of the tropopause (chemical definition of 150 ppb ozone level from run ${ }^{\mathrm{LL}}$ experiments). 

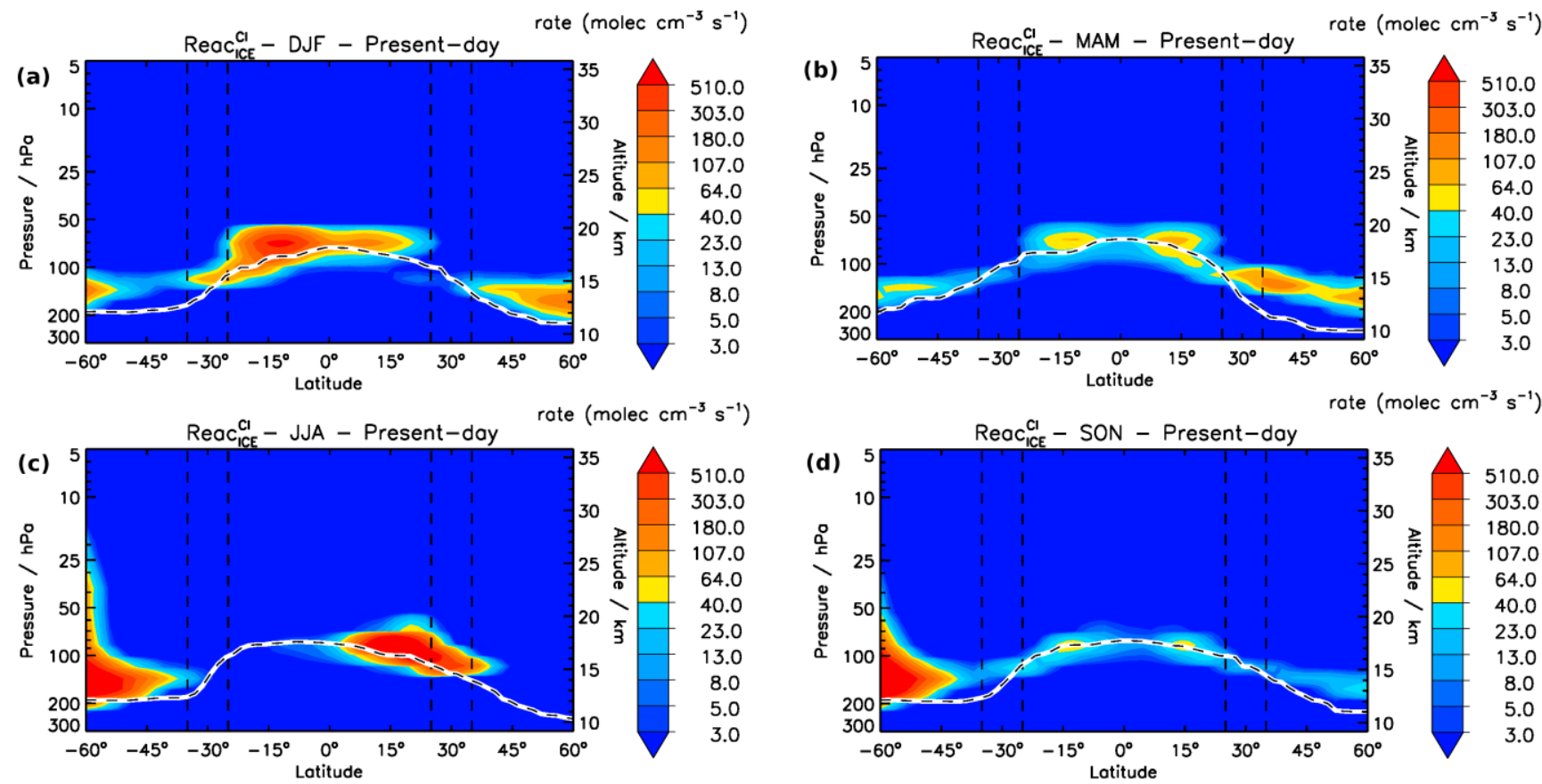

Figure S3: Seasonal zonal mean distribution of the heterogeneous reactivation of $\mathrm{ClONO}_{2}\left(\mathrm{Het}_{2,4}\right)$ and $\mathrm{HOCl}$ (Het5) on ice-crystal during the present-day period. The reactions have been specified in table S1 with the label Het and the corresponding number. 

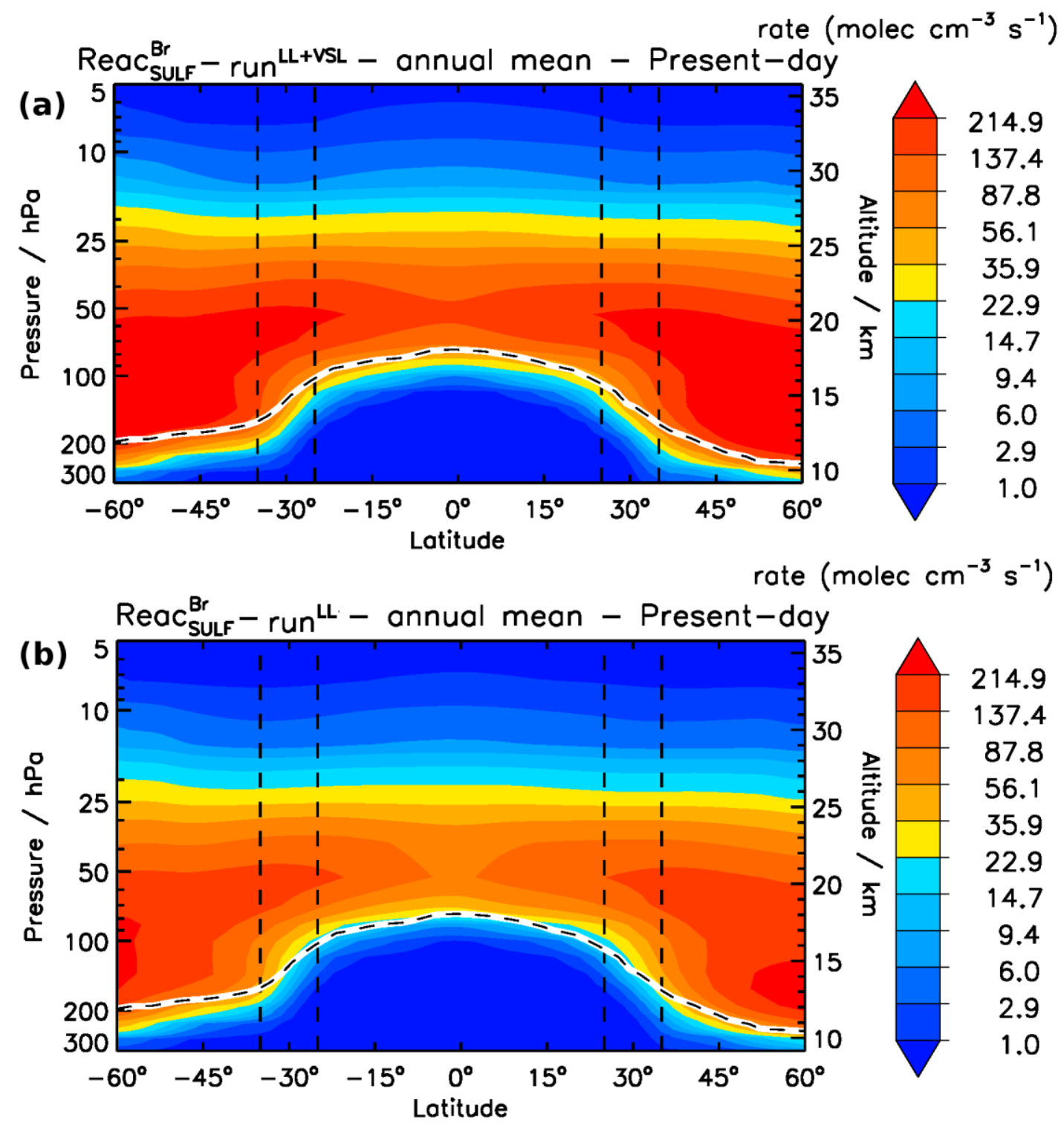

137.4

87.8

56.1

35.9

22.9

14.7

9.4

6.0

2.9

1.0

Figure S4: Annual zonal mean distribution of the heterogeneous reactivation of $\mathrm{BrONO}_{2}(\mathrm{Het9})$ and $\mathrm{HOBr}$ (Het12) on sulphate aerosols for the $\operatorname{run}^{\mathrm{LL}+\mathrm{VSL}}$ (a) and $\operatorname{run}^{\mathrm{LL}}$ (b) experiments during the present-day period. The reactions have been specified in table $\mathrm{S1}$ with the label Het and the corresponding number. 

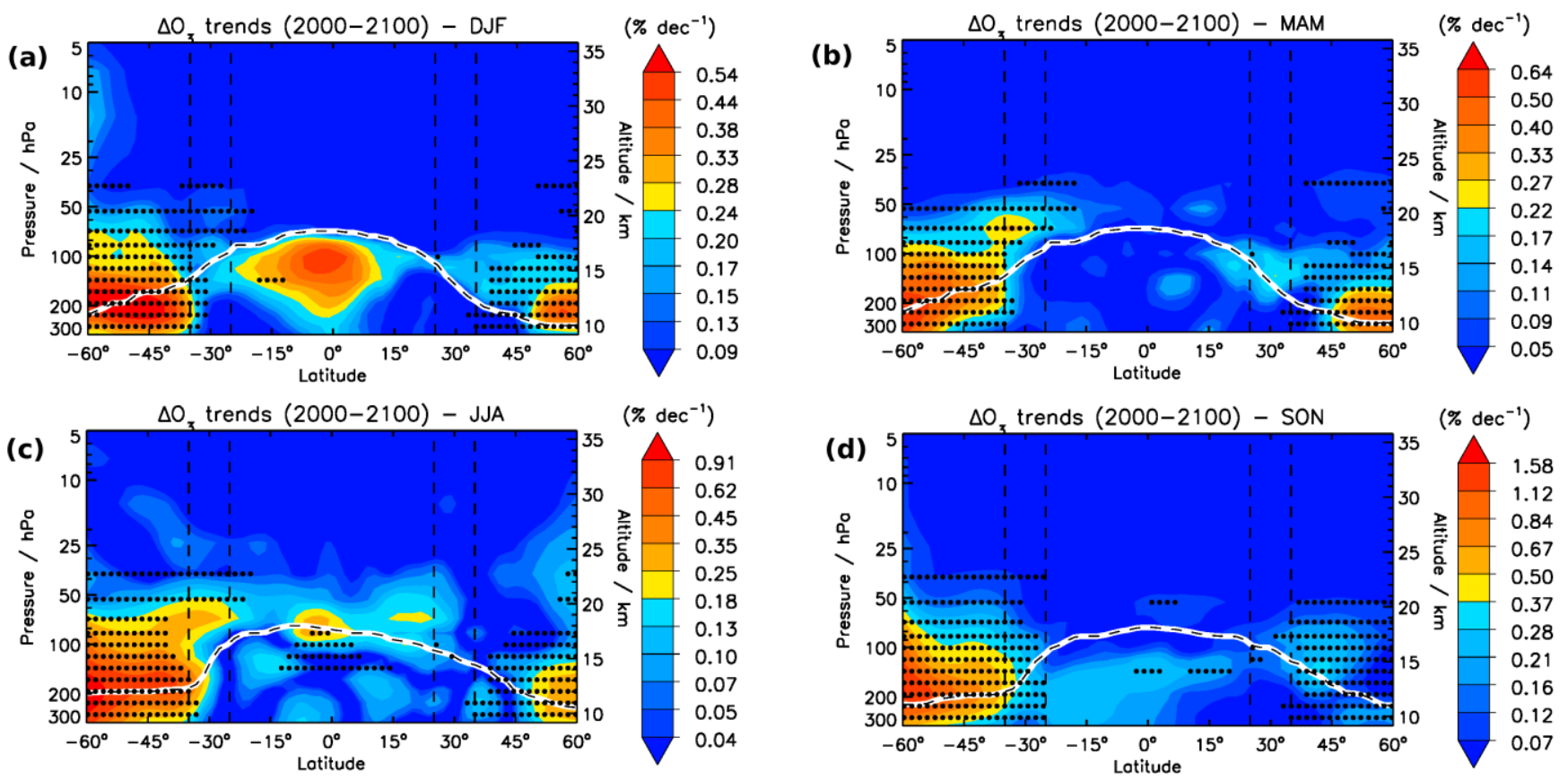

Figure S5: Zonal mean distributions of the seasonal $\Delta \mathrm{O}_{3}(z)$ trends $\left(\% \mathrm{dec}^{-1}\right)$ over the century. The masked regions in the left panels indicate where of seasonal relative $\Delta \mathrm{O}_{3}(z)$ between the present-day and the end of the $21^{\text {st }}$ century periods are statistically significant at the $95 \%$ confidence interval using a two-tailed Student's $t$ test. 


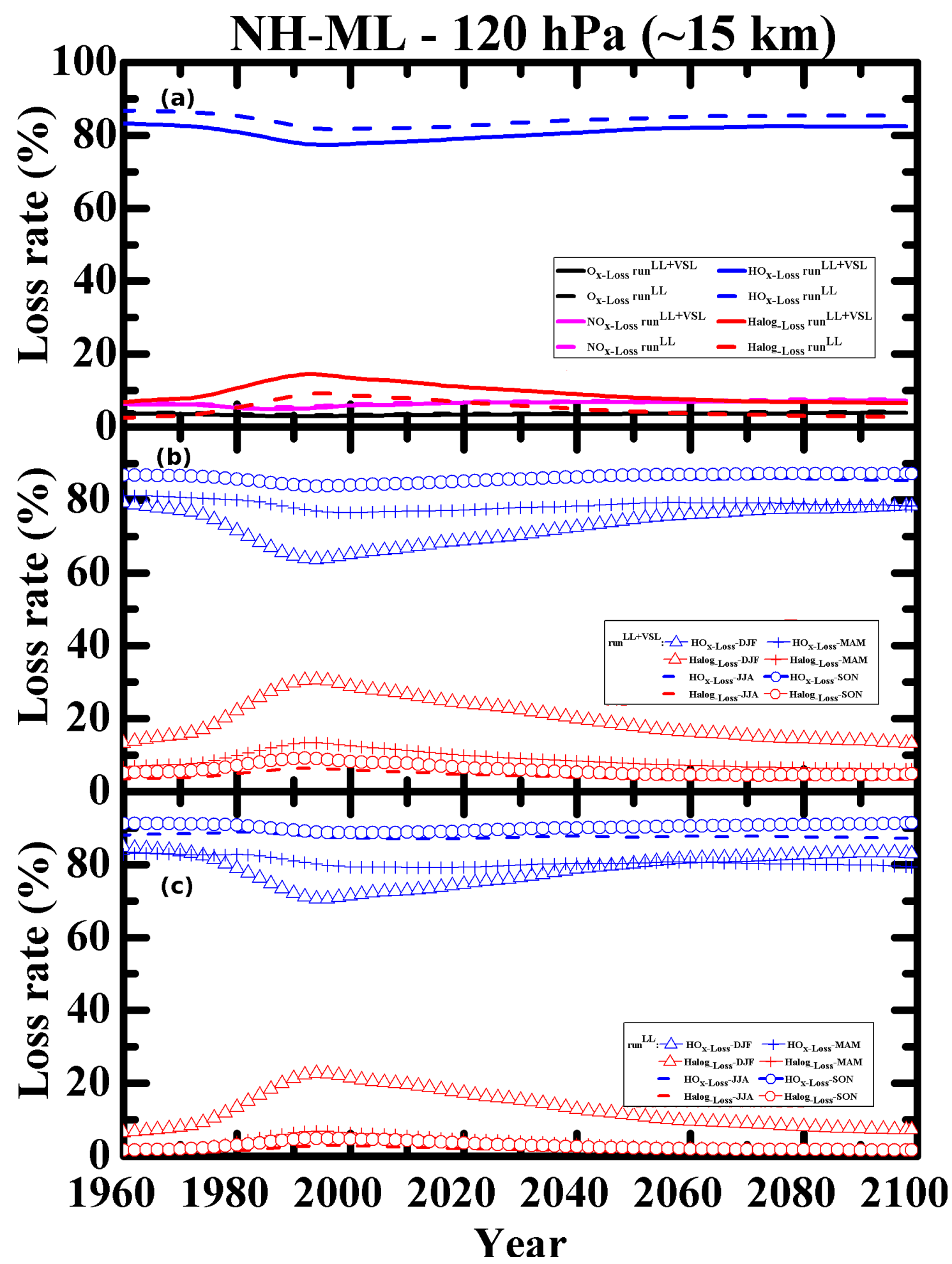

Figure S6: As Fig. 8 but for the lowermost stratosphere (120 hPa) at northern hemisphere mid-latitudes (NHML). 


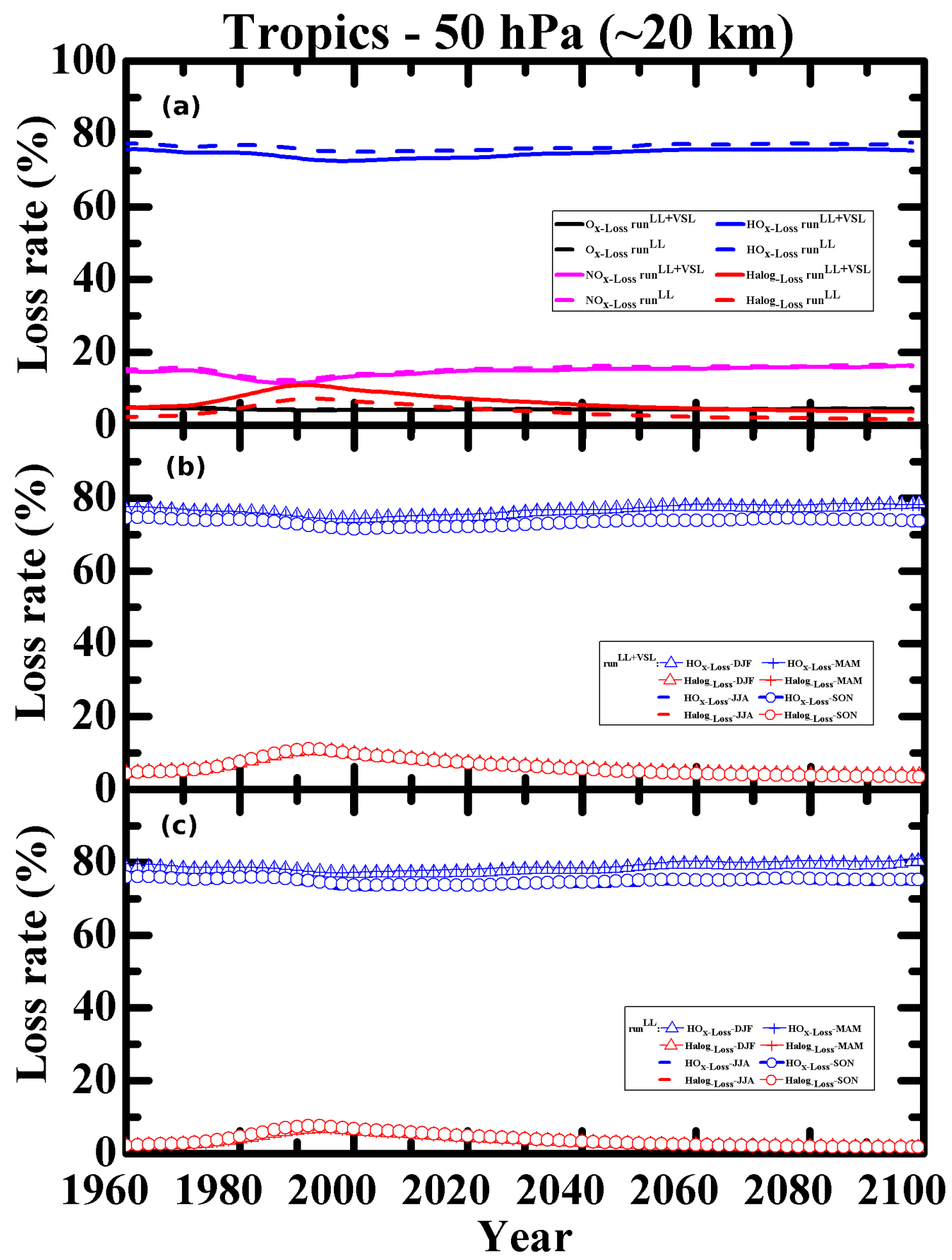

Figure S7: As Fig. 8 but for the lower stratosphere (50 hPa) at tropics. 

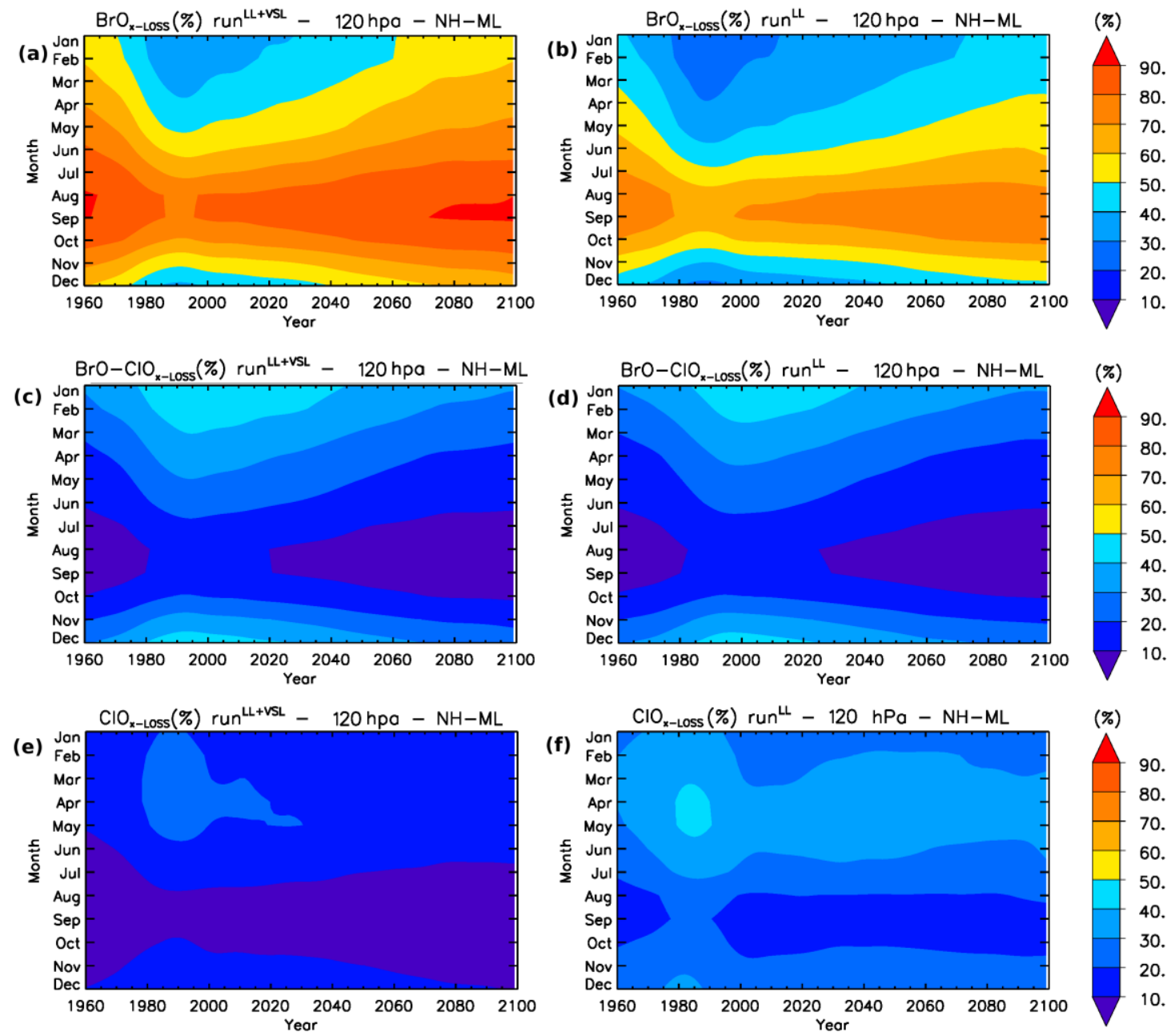

Figure S8: As Fig. 9 but for the lowermost stratosphere $(120 \mathrm{hPa})$ at northern hemisphere mid-latitudes (NHML). 

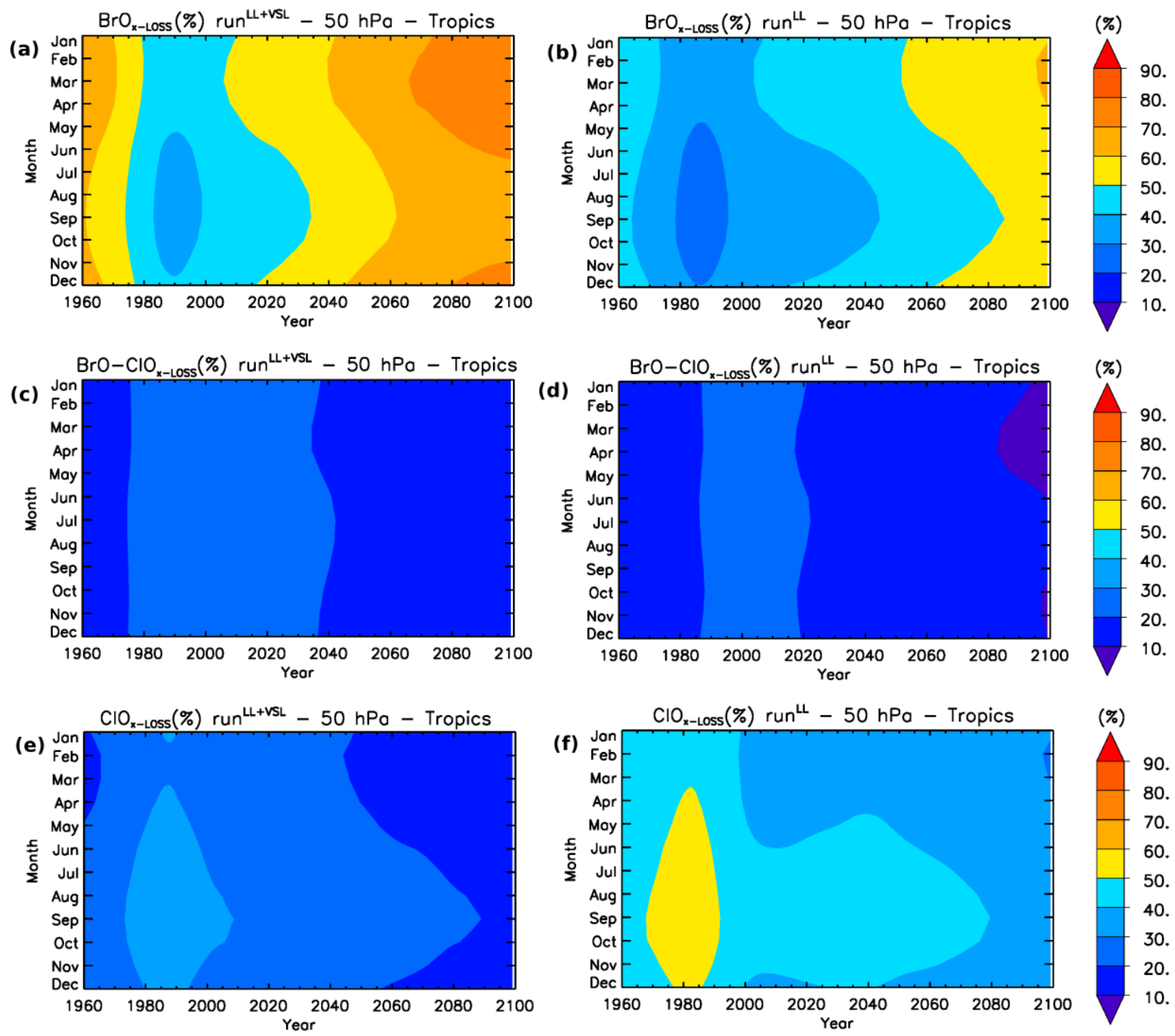

Figure S9: As Fig. 9 but for the lower stratosphere $(50 \mathrm{hPa})$ at tropics.

\section{References}

Kinnison, D. E., Brasseur, G. P., Walters, S., Garcia, R. R., Marsh, D. R., and Sassi, F., Harvey,

V. L., Randall, C. E., Emmons, L., Lamarque, J. F., Hess, P., Orlando, J. J., Tie, X. X., Randel, W., Pan, L. L., Gettelman, A., Granier, C., Diehl, T., Niemeier, U., and Simmons, A. J.: Sensitivity of chemical tracers to meteorological parameters in the MOZART-3 chemical transport model, J. Geophys. Res.112, D20302, doi:10.1029/2006JD007879, 2007.

Ordóñez, C., Lamarque, J.-F., Tilmes, S., Kinnison, D. E., Atlas, E. L., Blake, D. R., Sousa Santos, G., Brasseur, G. and Saiz-Lopez, A.: Bromine and iodine chemistry in a global chemistryclimate model: description and evaluation of very short-lived oceanic sources, Atmos. Chem. Phys., 12, 1423-1447, https://doi.org/10.5194/acp-12-1423-2012, 2012. 